\title{
STUDI PENGARUH PENAMBAHAN SERAT TERHADAP KUAT TEKAN DAN KUAT LENTUR ATAP SERAT BULU AYAM
}

\author{
Sri Handani dan Denia Efilusi \\ Jurusan Fisika FMIPA Univesitas Andalas \\ Email : shandani69@yahoo.com
}

\begin{abstract}
ABSTRAK
Telah dilakukan penelitian untuk mengetahui pengaruh penambahan serat terhadap kuat tekan dan kuat lentur atap serat bulu ayam dengan variasi serat 30\%, 40\%, 50\%, dan $60 \%$. Untuk pengujian kuat tekan, atap dibuat dengan ukuran $5 \mathrm{~cm}$ x $5 \mathrm{~cm}$ x $6 \mathrm{~cm}$, dan ukuran $10 \mathrm{~cm}$ x $5 \mathrm{~cm}$ x $3 \mathrm{~cm}$ untuk pengujian kuat lentur. Hasil penelitian menunjukkan bahwa komposisi optimum serat bulu ayam adalah $30 \%$ yang memberikan nilai kuat tekan atap sebesar $38 \mathrm{Mpa}$, dan kuat lentur sebesar 27.8 MPa. Pada komposisi yang sama, nilai kuat tekan atap serat kaca lebih lebih kecil daripada atap serat bulu ayam, sedangkan nilai kuat lenturnya lebih besar dibandingkan atap serat bulu ayam.
\end{abstract}

Kata kunci: kuat tekan, kuat lentur, serat bulu ayam, serat kaca

\section{PENDAHULUAN}

Atap serat bulu ayam merupakan suatu material komposit yang terbentuk dari dari dua jenis material yang berbeda yaitu penguat dan matriks sebagai pengikat. Penguat biasanya berupa serat, benang atau butiran (Bernins, 1991). Pengikat atau matriks biasanya menggunakan resin. Dalam penggunaannya resin biasanya dicampur dengan katalis. Perbandingan antara resin dan penguat merupakan faktor yang sangat penting untuk menentukan sifat strutur komposit (Schwartz, 1996). Selain bahan pengikat dan bahan penguat, material komposit juga tersusun dari beberapa bahan tambahan lainnya seperti pigmen, pengisi dan penguat (Surdia, 1987).

Serat bulu ayam dapat digunakan sebagai alternatif penguat selain serat sintetis seperti plastik karena bulu ayam yang tersusun dari keratin memiliki ikatan sistin disulfida yang cenderung berikatan satu sama lain sehingga menjadikannya kuat, tangguh dan ringan (Williams, dkk, 1991). Di samping itu pemanfaatan bulu ayam juga mengurangi pencemaran lingkungan yang disebabkan oleh pembakaran dalam proses pemusnahan serat sintetis (Richardson, 1987).

Dari penelitian yang dilakukan oleh Khoirul (2009) dan Setyawan (2009) tentang komposit berpenguat serat bulu ayam, kekuatan komposit maksimum masing-masing diperoleh pada fraksi volume serat $50 \%$ dan $60 \%$. Pada penelitian ini akan ditentukan kuat tekan dan kuat lentur atap serat bulu ayam dengan komposisi serat 30\%, 40\%, 50\% dan $60 \%$ lalu dibandingkan dengan kuat tekan dan kuat lentur atap serat kaca yang dibuat dengan komposisi serat yang sama dengan atap serat bulu ayam.

\section{METODE PENELITIAN}

\section{Bahan dan Peralatan}

Bahan-bahan yang digunakan dalam penelitian ini antara lain bulu ayam dari ayam tipe Broiler, resin Yucallac 157 dengan katalis mekpo, serat kaca, deterjen dan air, sedangkan peralatan yang digunakan adalah alat uji kuat tekan dan kuat lentur jenis Wekob 2153 Neu Wulmshorf, cetakan dari aluminium, timbangan digital, oven, kuas dan wadah plastik. 


\section{Prosedur Penelitian}

Bulu ayam yang berwarna putih dicuci bersih menggunakan deterjen. Selanjutnya bulu ayam tersebut dikeringkan di dalam oven pada suhu $130^{\circ} \mathrm{C}$ selama 1.5 jam. Setelah kering, bulu ayam dipisahkan dari tulangnya untuk mendapatkan seratnya. Serat bulu ayam kemudian dicampur dengan resin dengan persentase 40\%, 50\%, 60\% dan $70 \%$. Campuran resin dan serat bulu ayam lalu dimasukkan ke dalam cetakan dengan susunan seperti pada Gambar 1. Setelah kering, sampel dilepaskan dari cetakan.

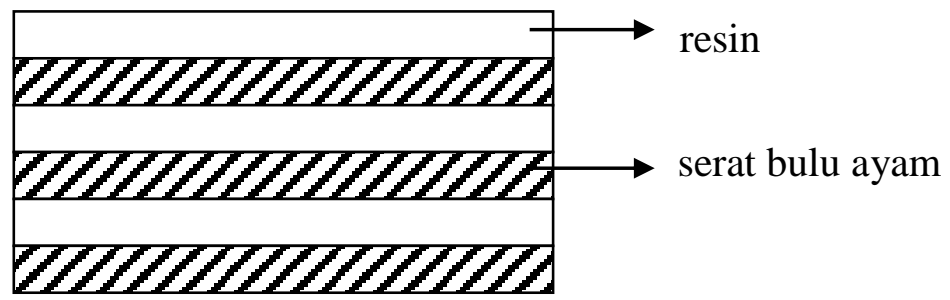

Gambar 1. Susunan lapisan serat bulu ayam dan resin

Sampel yang telah kering tersebut kemudian diuji kuat tekan dan kuat lenturnya menggunakan persamaan 1 dan 2.

$$
\sigma=\frac{F}{A}
$$

dengan

$$
\begin{aligned}
\sigma & =\text { kuat tekan }\left(\mathrm{N} / \mathrm{m}^{2}\right) \\
F & =\text { besar gaya yang diberikan }(\mathrm{N}) \\
A & =\text { luas permukaan yang diberi gaya }\left(\mathrm{m}^{2}\right) \\
W & =\frac{3 F l}{2 b h^{2}}
\end{aligned}
$$

dengan

$$
\begin{aligned}
& W=\text { kuat lentur benda uji }\left(\mathrm{kg} / \mathrm{cm}^{2}\right) \\
& F=\text { beban patah maksimum }(\mathrm{kN}) \\
& l=\text { jarak tumpuan }(\mathrm{cm}) \\
& b=\text { lebar rata }- \text { rata benda uji }(\mathrm{cm}) \\
& h=\text { tebal rata }- \text { rata benda uji }(\mathrm{cm})
\end{aligned}
$$

Hasil pengujian kuat tekan dan kuat lentur atap dengan serat bulu ayam kemudian dibandingkan dengan kuat tekan tekan dan kuat lentur atap serat kaca yang dibuat dengan cara yang sama dengan pembuatan atap serat bulu ayam.

\section{HASIL DAN PEMBAHASAN}

Hasil pengujian kuat tekan dan kuat lentur atap serat bulu ayam dan atap serat kaca dapat dilihat pada Gambar 2 dan Gambar 3. Berdasarkan penelitian yang telah dilakukan, diperoleh nilai kuat tekan paling tinggi pada komposisi bulu ayam 30\% yaitu sebesar $38 \mathrm{MPa}$. Pada komposisi serat bulu ayam 40\%, nilai kuat tekannya sebesar $31 \mathrm{Mpa}$. Nilai ini sama dengan nilai kuat tekan pada komposisi serat bulu ayam $0 \%$, artinya resin sendiri sudah mempunyai sifat mekanis yang bagus. Pada komposisi serat bulu ayam 50\% 
diperoleh nilai kuat tekan sebesar $29 \mathrm{MPa}$ dan untuk komposisi $60 \%$ diperoleh nilai kuat tekan $27 \mathrm{MPa}$. Pada komposisi 60\% diperoleh nilai kuat tekan paling rendah karena penambahan serat bulu ayam yang terlalu banyak dapat menyebabkan resin tidak mampu untuk mengikat serat, akibatnya terbentuk kekosongan pada sampel sehingga menurunkan nilai kuat tekan.

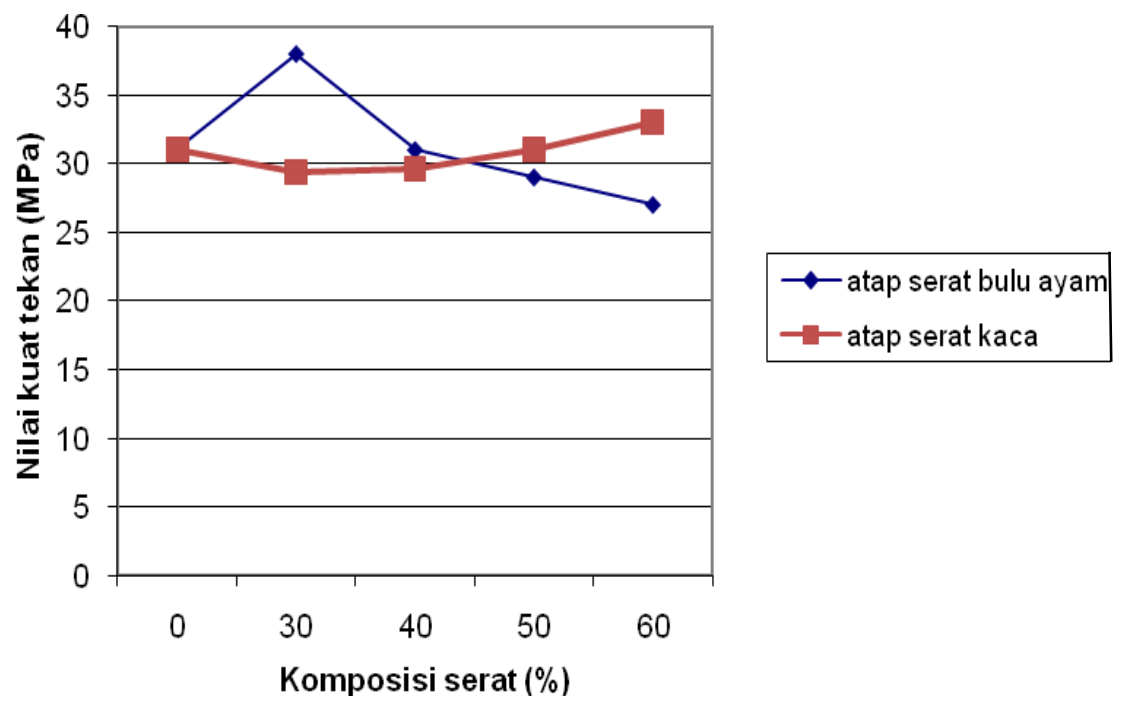

Gambar 2. Grafik nilai kuat tekan atap serat bulu ayam dan atap serat kaca

Sebagai pembanding, dilakukan juga pengujian kuat tekan dan kuat lentur atap serat kaca. Untuk atap serat kaca didapatkan nilai kuat tekan tertinggi pada komposisi serat 60\% yaitu 33 Mpa. Pada komposisi tersebut terbentuk ikatan yang kuat antara matriks dan serat sehingga kuat tekan sampel lebih tinggi daripada komposisi yang lain. Pada komposisi serat 50\% dan 40\% nilai kuat tekannya masing-masing $31 \mathrm{MPa}$ dan $29.6 \mathrm{Mpa}$. Nilai kuat tekan paling rendah diperoleh pada komposisi serat $30 \%$ yaitu $29.4 \mathrm{MPa}$. Terlihat bahwa nilai kuat tekan atap serat kaca akan menurun jika seratnya dikurangi. Ini disebabkan karena melemahnya ikatan antara serat dengan matriks yang mengakibatkan sampel mudah retak.

Dalam penelitian ini, pada komposisi serat yang sama misalnya $30 \%$, didapatkan nilai kuat tekan atap serat bulu ayam lebih besar daripada atap serat kaca. Tapi jika dibandingkan dengan nilai ASTM (D695-2004) kedua nilai ini jauh di bawahnya. Nilai kuat tekan atap serat kaca berdasarkan ASTM adalah $135 \mathrm{MPa}$. Nilai yang lebih rendah ini disebabkan teknis pembuatan sampel yang tidak sama. Sampel-sampel yang dibuat ASTM menggunakan mesin sehingga hampir tidak memiliki kekosongan, sedangkan sampel dalam penelitian ini dibuat secara manual sehingga kurang homogen dalam pengadukan dan terdapat banyak kekosongan. Faktor lain yang mempengaruhi perbedaan nilai kuat tekan atap yaitu adanya bahan tambahan seperti pigmen dan bahan pengisi yang digunakan untuk meningkatkan kemampuan pemrosesan atau untuk mengubah kualitas dan sifat produk suatu bahan.

Kekuatan bahan komposit juga dipengaruhi oleh distribusi serat dalam matriks, orientasi serat dan ikatan antara matriks dan serat. Pada penelitian ini atap dibuat dengan orientasi serat yang acak, sementara sampel ASTM menggunakan orientasi serat searah. Jika orientasi serat acak, maka ikatan yang terjadi antara matriks dan serat melemah sehingga sifat-sifat mekanis pada setiap arah akan menjadi lebih kecil. 


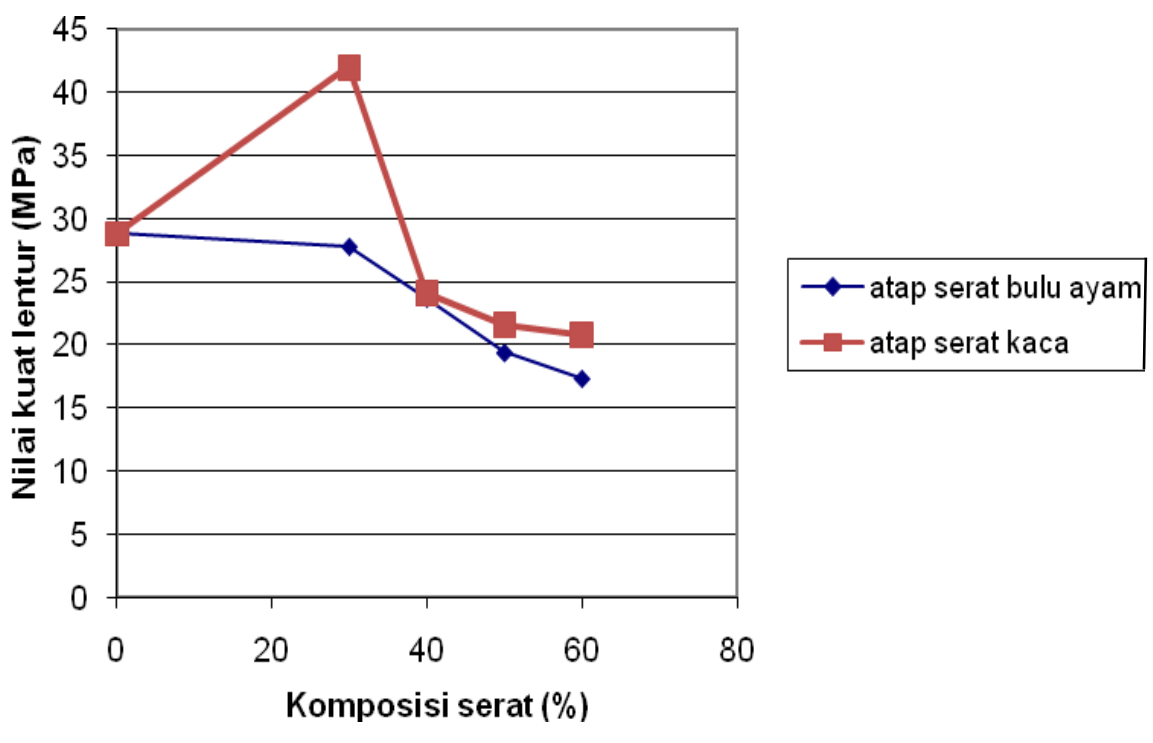

Gambar 3. Grafik nilai kuat lentur atap serat bulu ayam dan atap serat kaca

Dari pengujian kuat lentur, didapatkan nilai kuat lentur paling tinggi baik pada atap serat bulu ayam maupun atap serat kaca yaitu pada komposisi serat $30 \%$ dengan nilai kuat lentur masing-masingnya adalah $27.8 \mathrm{MPa}$ dan $42 \mathrm{MPa}$.

Berdasarkan Gambar 3 terlihat bahwa pada komposisi serat yang semakin meningkat, nilai kuat lentur cenderung semakin menurun. Secara umum pada semua komposisi serat, nilai kuat lentur atap bulu ayam lebih rendah daripada atap serat kaca. Menurut ASTM (D790-2003) nilai kuat lentur atap serat kaca sebesar $241 \mathrm{MPa}$. Perbedaan ini disebabkan oleh teknis pembuatan seperti pemakaian katalis, jenis resin, jenis serat dan bahan tambahan yang digunakan. Pada penelitian ini katalis yang digunakan terlalu banyak sehingga sampel menjadi getas dan mudah patah. Resin polyester yang digunakan mempunyai nilai kuat lentur sebesar $28.8 \mathrm{MPa}$, sementara pada standar ASTM resin yang digunakan mempunyai nilai kuat lentur yang lebih tinggi. Demikian juga pada sampel ASTM digunakan serat penguat, lapisan plastic dan bahan tambahan yang berkualitas tinggi, sehingga kekuatan lenturnya menjadi lebih bagus.

Selain teknik pembuatan, orientasi dan diameter serat juga mempengaruhi nilai kuat lentur. Pada atap serat kaca digunakan orientasi serat searah, sedangkan pada atap bulu ayam orientasi seratnya acak. Jika orientasi serat acak, maka sifat-sifat mekanis pada setiap arah menjadi rendah. Terkait dengan diameter serat, semakin kecil diameter serat maka akan semakin besar kekuatannya.

\section{KESIMPULAN}

Berdasarkan hasil yang diperoleh maka dapat disimpulkan bahwa nilai kuat tekan dan kuat lentur paling tinggi pada atap serat bulu ayam adalah pada komposisi serat $30 \%$ yaitu masing-masing sebesar $38 \mathrm{MPa}$ dan $27.8 \mathrm{MPa}$, sedangkan nilai kuat tekan dan kuat lentur paling rendah adalah pada komposisi serat 60\% yaitu masing-masing sebesar 27 $\mathrm{MPa}$ dan 17.3 MPa. Untuk atap serat kaca, nilai kuat tekan paling tinggi pada komposisi serat $60 \%$ yaitu sebesar $33 \mathrm{MPa}$ dan paling rendah pada komposisi serat $30 \%$ yaitu sebesar 29.4\%. Sedangkan nilai kuat lentur paling tinggi atap fiberglass adalah pada komposisi serat $30 \%$ yaitu sebesar $42 \mathrm{MPa}$ dan paling rendah pada komposisi serat $60 \%$ yaitu sebesar 20.8 MPa. 


\section{DAFTAR PUSTAKA}

1. Bernins, M., 1991, Plastics Engineering, Handbook The Society of Plastics Industry Inc., New York.

2. Schwartz, M., 1996, Composites Material Polimer, Ceramics and Metal Matrices, Prentice Hall, USA.

3. Surdia, T., 1987, Pengetahuan Bahan teknik, Edisi keenam, PT. Pradnya Paramitha, Jakarta.

4. Williams, C. M., Lee, C. G., Garlich, J. D., dan Jason, C. H., 1991, Evaluation of Bacterial Feather Formation Product, Industry Inc., New York.

5. Richardson, T., 1987, Composites, Industrial Press Inc., New York.

6. Khoirul, A., 2009, Pengaruh Fraksi Volume Serat Bulu Ayam, Skripsi S-1, Jurusan Fisika, Universitas Sumatera Utara, Medan.

7. Setyawan, T., 2009, Pengaruh Fraksi Volume Serat Terhadap Kekuatan Komposit Serat Rachis Bulu Ayam, Skripsi S-1, Jurusan teknik Mesin, Universitas Islam Indonesia, Yogyakarta. 